\title{
Genome project to tackle mass screening
}

\section{- Cystic fibrosis pilot planned - Concern over genome map delays}

\section{Washington}

Planners on the Human Genome Project last week tentatively agreed to take the lead in a pilot project to screen the public for cystic fibrosis (CF) in what will be the first such project in the United States. At a meeting of the project's advisory committee, panel members advised project director James Watson to start looking for government and private partners in a pilot screening project.

Several of the National Institutes of Health (NIH) have expressed interest, as have other branches of the US government, including the Agency for Health Care Policy Research, a branch of the Public Health Service.

Scientists have been working to map and sequence the human DNA molecule for two years while widespread testing for genetic diseases - a major application of the research - has languished. But before widespread testing can begin, policymakers must tackle legal and ethical issues that have prevented the setting up of any genetic screening trials in the United States while trials have gone ahead elsewhere.

Unlike countries such as the United Kingdom and Denmark which have already begun testing, the United States has no public health programme. The CF test is expensive - about $\$ 300$ per sample beyond the pocket of many potential subjects.

With mass testing and greater coordination, those costs could drop. Fewer than 3,000 CF tests are at present processed each year in the United States. In contrast, Britain, where laboratories this year will process some 50,000 samples and where public health care pays for much of the education, counselling and follow-up service, the tests cost only $\$ 2$ each.

US policy-makers must also overcome a shortage of testing laboratories and genetic counsellors. A draft report from the genome project's working group on ethics, legal and social issues points out that "there are 3.5-4 million births in the United States each year. If even a small fraction of those requested $\mathrm{CF}$ testing, the system would be overwhelmed." There are fewer than 1,000 genetic counsellors in the United States, and only 75 new master's level counsellors are trained each year, the report notes.

These logistical problems are overshadowed by the abortion issue: critics claim that testing is simply a rationale for abortion, leading some genetic disease organizations to shy away from screening as one controversy they can do without.

Although many private health insurers will now pay for genetic testing, some do so only with the agreement that the fetus will be aborted if it shows a high probability of developing a serious - and expensive - disease. Research into such discrimination against carriers of $\mathrm{CF}$ and other genetic diseases will be funded by the genome project -4 per cent of the total budget is marked for ethics research.

The debate about CF is further complicated by the disease's complex genetic origin. The defective gene, discovered last year, is found in only some three-quarters of those who carry a genetic weakness for CF. Various mutations of the gene account for the rest. At best, current US tests can identify only 84 per cent of the carriers. Some groups have called for a moratorium on testing until a 95 per cent detection rate is reached, but without a research breakthrough, the 90 per cent rate now achieved by one Danish group may be the practical limit.

Deciding which of these issues are serious hurdles and which have simple solutions must wait for a large-scale pilot project. "These are all research questions and you need a research setting to answer them", says Nancy Wexler, who directs the genome project's ethics working group. "The main thing is that somebody says "We have to take responsibility for these projects"'. But some genome project planners are concerned that becoming involved in genetic screening could shift the emphasis of the effort from basic research to public policy - and delay the completion of the genome map.

Breast cancer and diabetes now seem to have genetic links, and a workable test would no doubt spur calls for widespread screening for them as well. "Once you let the camel's nose under the tent, how do you keep the whole camel out?" asked Norton Zinder, chairman of the genome advisory committee, last week

Wexler, however, does not believe that pilot screening projects will divert the genome project from its goal. "Once you work out the questions for one disease, you're in a better position for the next one", she says. And funding for the CF pilot project, if approved, will come out of the 4 per cent ethics budget, not from research funds, she points out.

Christopher Anderson
NASA woes are self-
inflicted says report

\section{Washington}

THE future of the US space programme depends on cutting costs, setting new goals and scaling down big projects like Space Station Freedom, the Augustine commission on NASA's long term future reported on Monday.

Some concerns over NASA's activities are "deserved, and occasionally even selfinflicted", says the report.

The greatest flaw is that there is no clear purpose to the space programme. NASA has been trying to do too many different things with limited resources, and has contributed to its own downfall by underestimating project costs and safety margins, then cutting back smaller projects to keep the larger ambitions alive.

The committee says some goals must be set aside or postponed until money can be found to pay for them.

NASA's highest priority should be a science programme, using primarily unmanned launch vehicles. Next should be a Mission to Planet Earth, to provide comprehensive data for the global environmental debate, and only after that should manned space exploration be contemplated. The trip to Mars is a suitable long-term goal but it should be made of achievable steps which could be accomplished as money and technology allow.

In specific terms, the space shuttle should be retained as the basic means of ferrying people into space, but a new fleet of rockets should be the workhorses of the scientific space programme.

The space station will not immediately be needed as a transportation mode for manned exploration and should be rethought. Its chief purpose should be to conduct life science studies in weightless conditions, and the present 90 -day redesign period ordered by Congress should be extended, if necessary, so that a space station with specific purposes and the ability to achieve them will be created.

The prospect of further redesigns does not trouble the Europeans at this stage, according to Ian Pryke of the European Space Agency's Washington office, who agrees that is is more important to get things right than to stick to a rigid timetable.

The committee chaired by Norman Augustine, formerly head of the aerospace company Martin Marietta was set up six months ago at the request of US VicePresident Dan Quayle (see Nature 346, 206; 1990).

At that time the flaw in the Hubble Space Telescope had just come to light, the space shuttle fleet was grounded by persistent fuel leaks, and the feasibility of the space station was being questioned.

David Lindley 